Красинский Владислав Вячеславович кандидат юридических наук, эксперт Российского общественного института избирательного права (РОИИП)

Красинский B.B. Лишение избирательного права в зарубежных странах // Журнал зарубежного законодательства и сравнительного правоведения. М.: Институт законодательства и сравнительного правоведения при Правительстве РФ, 2008. № 15 (вып. 4). С. 49-53; www.krasinskiy.ru

\title{
ЛИШЕНИЕ ИЗБИРАТЕЛЬНОГО ПРАВА В ЗАРУБЕЖНЫХ СТРАНАХ
}

История демократического развития выборов в зарубежных странах на протяжении нескольких последних веков представляет собой расширение всеобщности избирательного права и увеличение электората большинства государств. Эта тенденция проявилась в предоставлении избирательного права женщинам, чернокожему населению, снижении возрастного ценза, отмене имущественного и образовательного цензов, ликвидации плюрального вотума. Вместе с тем нормативные правовые акты, регулирующие избирательный процесс в зарубежных странах, на сегодняшний день продолжают сохранять положения, ограничивающие субъективное избирательное право отдельных категорий граждан, а в ряде случаев - устанавливают возможность лишения избирательного права. Несовершенство юридической техники (отсутствие строгого понятийного аппарата, закрепление оснований ограничения и лишения избирательного права в одних и тех же статьях нормативных правовых актов, формулирование ограничительных конструкций с одновременным использованием положений о лишении избирательного права), упрощенные подходы к пониманию правовой природы ограничений и лишения субъективного избирательного права приводят к ложному отождествлению этих понятий. В теории избирательного права и конституционноправовой практике следует различать «ограничение избирательного права» как законодательные требования к избирательному корпусу и кандидатам и «лишение избирательного права» как меру предупреждения девиантного поведения граждан или меру наказания, применяемую к правонарушителям.

Ограничение избирательного права в большинстве стран предполагает общеобязательные правовые требования к гражданству, возрасту, продолжительности и сроку проживания на определенной территории, профессиональной принадлежности избирателей и кандидатов на выборные должности. Эти требования закрепляются главным образом в конституционном или выборном законодательстве зарубежных стран. 
Например, в Германии согласно § 12 разд. 3 федерального Закона ФРГ о выборах от 7 мая 1956 года (с изм. от 11 марта 2005 г.) (Bundeswahlgesetz) избирательным правом обладают все лица, являющиеся немцами, которые на день выборов: достигли 18-летнего возраста, имеют жилище или иным надлежащим образом проживают в ФРГ не менее 3 месяцев, а также не лишены избирательного права. Пассивное избирательное право ограничивается в отношении чиновников, государственных служащих, военнослужащих, судей ${ }^{1}$. В соответствии с Формой правления Швеции 1974 г. возрастной ценз во все выборные органы власти составляет 18 лет, ценз оседлости при выборах в собрания уполномоченных ландстингов и коммун для граждан государств-членов ЕC, а также граждан Норвегии и Исландии - 30 дней, для граждан иных государств - 3 года ${ }^{2}$ По закону Канады о выборах от участия в выборах в качестве кандидата отстраняются в силу предписаний о несовместимости мандата депутаты законодательных органов провинций и территорий; шерифы; клерки мирового суда или атторней графства, а также судьи, назначенные на должность актом генерал-губернатора. Запреты касаются также любых должностных лиц по выборам³.

Сущность ограничения избирательного права заключается в законодательном сужении правовых возможностей субъекта права реализовать принадлежащие ему субъективные избирательные права (активное или (и) пассивное). Данное ограничение правосубъектности носит устранимый характер. Для вступления субъекта права в правоотношения, связанные с выборами органов публичной власти, требуется возникновение определенного фактического состава или юридического факта достижение определенного возраста, пребывание на территории государства в течение установленного законом периода времени, увольнение с гражданской или военной службы, оставление сана и т.д. Основанием ограничения избирательного права выступает фактическое поведение и правовое положение субъекта права, не соответствующее юридическим требованиям, предъявляемым к избирателям и (или) кандидатам на выборные должности. Ограничение активного избирательного права направлено на образование избирательного корпуса, способного по своим качественным характеристикам самостоятельно, осознанно и ответственно формировать органы народного представительства. Целями ограничения пассивного избирательного права

${ }^{1}$ См. Bundesgesetz BGB1. I S. 1288, 1594; BGB1. I S. 674; BGB1. I S. 1376; BGB1. I S. 1951.

${ }^{2}$ См. Современные избирательные системы. Вып. 2: Аргентина, Германия, Швеция. М.: РЦОИТ: Норма, 2007. С. 222. См. также Elections in Sweden / Right to vote and eligibility. S. 4 // www.val.se.

3 См. Современные избирательные системы. Вып. 1: Великобритания, Канада, Мексика, Польша. М.: Норма, 2006. С. 207. 
являются: обеспечение политической независимости представителей обозначенных в законе государственных органов, защита прав избирателей, ограничение возможностей кандидатов использовать служебное положение (административный ресурс) в условиях выборов.

Лишение избирательного права заключается во временной или бессрочной утрате субъектом права субъективного избирательного права, являющейся мерой превентивного или карательного характера. Лишение избирательного права может быть связано как с правомерным (недееспособность), так и с противоправным поведением субъектов права (совершение правонарушений). Лишение избирательного права (активного и (или) пассивного) кроме ограничения правосубъектности недееспособных лиц означает основное или дополнительное уголовное наказание, которое закреплено в санкции нормы права, носит личный характер и назначается судом с учетом общественной опасности правонарушения. Так, законодательство Польши предусматривает возможность лишения избирательного права как в качестве основного, так и дополнительного наказания. В Аргентине лишение избирательного права на срок от 1 года до 10 лет назначается в качестве дополнительного наказания за совершение деяний, наказуемых в соответствии с нормами национального избирательного законодательства. Согласно канадскому законодательству совершение правонарушений, создающих препятствие нормальному ходу избирательного процесса, в качестве дополнительного наказания предусматривает лишение пассивного избирательного права на определенный срок или права занимать какие-либо должности, связанные с обеспечением избирательного процесса.

Во многих зарубежных странах лица, отбывающие наказание в местах лишения свободы по приговору суда ограничены в избирательном праве или лишены его. В Австрии, Бельгии, Франции, Германии, Греции, Италии, Люксембурге, Мальте, Нидерландах, Норвегии, Польше, Румынии и Турции существуют ограничения избирательного права заключенных. В Армении, Азербайджане, Болгарии, Эстонии, Грузии, Ирландии, Латвии, Лихтенштейне, Молдавии, Российской Федерации, Словакии и Великобритании заключенные лишены права голоса. В этой связи представляет интерес практика Европейского суда по правам человека, связанная с защитой избирательного права осужденных лиц. 6 октября 2005 г. Большая палата Grand Chamber Европейского суда по правам человека вынесла окончательное решение по делу Хирст против Соединенного Королевства (Hirst v. The United Kingdom (No. 2) (application No. 74025/01). Заявитель, Джон Хирст, приговоренный к пожизненному лишению свободы, обжаловал положения ст. 3 Акта о народном представительстве 1983 г. о запрете принимать участие в голосовании на выборах в Парламент или местные органы власти. Европейский Суд 
признал несоответствие ст.3 Закона о народном представительстве Протоколу № 1 Конвенции о защите прав человека. По мнению Суда, запрет на участие заключенных в голосовании на выборах не должен распространяться на всех осужденных, кроме того, данное ограничение должно применяться в зависимости от срока назначенного наказания и тяжести правонарушения. Европейский Суд предоставил Великобритании право самостоятельно избрать способ обеспечения избирательных прав заключенных ${ }^{4}$.

Целями лишения избирательного права являются: поддержание авторитета закона, исключение возможности криминального влияния на формирование органов народного представительства, недопущение правонарушителей в выборные органы власти. В отличие от ограничения избирательного права, лишение избирательного права в зарубежных странах может носить как устранимый (истечение срока наказания, помилование, амнистия), так и неустранимый характер (пожизненное тюремное заключение с бессрочным лишением, недееспособность вследствие неизлечимого психического заболевания). Лишение избирательного права осуществляется на основе судебного решения путем исключения лица из Реестра избирателей. В ряде государств (например, в Аргентине) при подготовке списков избирателей составляется отдельная картотека недееспособных граждан и лиц, исключенных из списков избирателей. Конкретные основания, сфера и продолжительность действия, механизм реализации лишения избирательного права устанавливаются конституционным, выборным и уголовным законодательством.

Лишение избирательного права нельзя отождествлять с другим видом уголовного наказания - лишением права занимать публичные должности. Лишение права занимать публичные должности предполагает исключение доступа правонарушителя не только к выборным, но и назначаемым публичным должностям. Наказание в виде лишения права занимать публичные должности нередко назначается судом вместе с лишением правонарушителя избирательного права, поскольку иначе у данного лица сохраняется возможность быть назначенным на публичные должности и осуществлять властные полномочия. Так, в Аргентине лица, подвергнутые тюремному наказанию за совершение

4 См. Международные избирательные стандарты. Сб. документов. М., 2004. В государствах, где заключенные имеют право голоса (Албания, Босния и Герцеговина, Кипр, Хорватия, Чехия, Дания, Финляндия, бывшая югославская республика Македония, Исландия, Литва, Португалия, Словения, Испания, Швеция, Швейцария и Украина), они реализуют свое избирательное право путем голосования по почте, по доверенности и другими предусмотренными законом способами. 
преступлений, связанных с выборами, лишаются права занимать публичные должности на срок не менее 2 лет 5 .

По времени действия различают пожизненное лишение избирательного права и лишение избирательного права на определенный срок. Согласно статьям L 5-8 Избирательного кодекса Франции лица, осужденные за преступления, лишаются избирательных прав пожизненно. В отношении осужденных за проступки в сфере избирательного права лишение избирательного права может носить временный характер 6 . В соответствии с $\S 45$ УК ФРГ лишение пассивного избирательного права осуществляется на срок от 2 до 5 лет. $\S 22$ разд. 2 Положения о порядке проведения выборов в Национальный Совет Австрии (Nationalratswahlordnung 1992) предусматривает лишение осужденных избирательного права на 6 месяцев ${ }^{7}$. В Китае политических (в том числе и избирательных) прав пожизненно лишаются лица, совершившие контрреволюционные преступления, а также осужденные к смертной казни и бессрочному лишению свободы ${ }^{8}$.

По сфере действия лишение избирательного права может распространяться на выборы в конкретном избирательном округе (локальное лишение) или на все виды выборов на всей территории государства (универсальное лишение права). Лицо, совершившее коррупционное правонарушение в сфере избирательного права Великобритании (мошенничество, неправомерное давление на избирателей, превышение предельных размеров предвыборных расходов, подкуп, фальсификацию документов о выдвижении кандидата), лишается пассивного избирательного права на 10 лет на территории всей страны. За осуществление незаконной практики (нарушение различных законодательных требований о доверенных лицах, использования помещений, рекламы, освещения предвыборной кампании, голосование более одного раза, голосование, несмотря на лишение права голоса и др.) к правонарушителю применяется лишение пассивного избирательного права на 5 лет на территории конкретного избирательного округа 9 .

${ }^{5}$ См. Современные избирательные системы. Вып. 2: Аргентина, Германия, Швеция. М.: РЦОИТ: Норма, 2007. С. 92, 93.

${ }^{6}$ См. Избирательный кодекс Франции // Journal Officiel de la Republique Franзaise, 26 janvier 1985. № 21.

${ }^{7}$ CM. Bundesgesetz BGB1. Nr. 47/ 1992; BGB1. I Nr. 28/2007.

${ }^{8}$ См. Зарубежное избирательное право: Учебное пособие. М.: Норма, 2003. С. 168.

${ }^{9}$ В соответствии с Актом о народном представительстве 1983 г. (the Representation of the People Act 1983) в избирательном праве Великобритании все правонарушения подразделяются на 2 вида - на коррупцию и незаконную практику (corrupt or illegal practices), что влечет для правонарушителя ограничение пассивного избирательного права. Аналогичная классификация правонарушений в сфере избирательного права принята и в Канаде. См. Зарубежное избирательное право: Учебное пособие. М.: Норма, 2003. С. 86. 
Основания лишения избирательного права могут корректироваться законодателем в зависимости от вида выборов. Например, по избирательному праву Великобритании пассивного избирательного права на любых выборах лишаются: лица, осужденные за коррупцию или иной вид нарушения избирательного права, за растрату государственных средств на сумму свыше 2000 фунтов стерлингов, либо лица, приговоренные к тюремному заключению на срок более трех месяцев в течение последних 5 лет без права замены наказания на штраф, и банкроты ${ }^{10}$. Особые основания лишения пассивного избирательного права предусмотрены на выборах в Парламент Великобритании. Они распространяются на: 1) лиц, на которых распространяется действие приказа о банкротстве (bankrutcy restriction order) в Англии или Уэльсе (Акт о предпринимательстве 2002 г. - The Enterprise Act 2002); лиц, которые были признаны в судебном порядке банкротами в Северной Ирландии, и лиц, чья собственность была конфискована в Шотландии; 2) лиц, отбывающим наказание в виде лишения свободы сроком свыше 12 месяцев; 3) лиц, занятых на службе у Короны (в частности, лиц, признанных виновными в совершении определенных правонарушений в сфере избирательного законодательства) ${ }^{11}$.

По содержанию изъятий объема правосубъектности лишение избирательного права делится на лишение активного избирательного права и лишение пассивного избирательного права. Решением Государственного трибунала Польской Республики лицо, совершившее преступление, связанное с нарушением Конституции или законов, может быть лишено как активного, так и пассивного избирательного права на всех видах выборов (п.1 ст. 23 Закона «О государственном трибунале» от 26 марта 1982 г.) ${ }^{12}$. В Канаде пассивного избирательного права лишены лица, отбывающие наказание в местах лишения свободы на срок свыше двух лет ${ }^{13}$.

По свободе усмотрения правоприменителя необходимо различать императивное и дискреционное лишение избирательного права. В случае императивного лишения избирательного права все основания лишения субъективного права четко предусмотрены действующим законодательством, и правоприменитель обязан ими руководствоваться. Дискреционное лишение избирательного права осуществляется по усмотрению суда с учетом общественной опасности правонарушения, личности правонарушителя и других юридически значимых обстоятельств. Мексиканское законодательство в императивной форме устанавливает случаи лишения права участвовать в выборах. В частности, это

${ }^{10}$ См. Зарубежное избирательное право: Учебное пособие. М.: Норма, 2003. С. 82.

11 См. Современные избирательные системы. Вып. 1: Великобритания, Канада, Мексика, Польша. М.: Норма, 2006. С. 76.

${ }^{12}$ См. Там же. С. 370.

${ }^{13}$ См. Там же. С. 207. 
право утрачивается в связи с лишением мексиканского гражданства по таким основаниям, как добровольное поступление на официальную службу иностранного правительства, принятие или ношение иностранных орденов, принятие титулов или выполнение поручений иностранного государства без разрешений Национального конгресса или его Постоянной комиссии, нанесение ущерба государству путем помехи иностранному правительству при рассмотрении дела международным судом ${ }^{14}$. Во Франции суды имеют право в зависимости от характера дела не лишать осужденных избирательных прав или, наоборот, дополнять основное наказание временным лишением избирательных прав ${ }^{15}$.

В зависимости от субъектов, принимающих решение о лишении избирательных прав, различаются судебное и несудебное лишение избирательного права. В большинстве государств лишение избирательного права в качестве меры основного или дополнительного наказания назначается судом. Примером несудебного лишения пассивного избирательного права является запрет Генерального Совета Федерального избирательного института Мексики на регистрацию кандидатов от определенной политической партии ${ }^{16}$.

К числу особых видов лишения избирательного права в зарубежных странах можно отнести: приостановление избирательного права; запрет регистрации в качестве кандидата от определенной политической партии; объявление неизбираемости на определенный срок. Особые виды лишения избирательного права имеют ряд общих черт, определяющих их правовую природу: устранимость (субъект права сохраняет возможность восстановления избирательного права), превентивный или карательный характер (карательные элементы лишения права направлены на прекращение субъектом права антиобщественного или противоправного поведения).

Приостановление избирательного права в законодательстве Мексиканских Соединенных Штатов подразумевает временную невозможность субъекта права участвовать в выборах. Данная разновидность временного лишения активного и пассивного избирательного права применяется судом в качестве меры предупреждения девиантного поведения к лицам, ведущим недостойный образ жизни (невыполнение конституционных обязанностей, уклонение от суда и следствия, бродяжничество, пребывание в приютах для наркоманов, систематическое пьянство). Срок

14 См. Современные избирательные системы. Вып. 1: Великобритания, Канада, Мексика, Польша. М.: Норма, 2006. С. 292.

${ }^{15}$ См. Зарубежное избирательное право: Учебное пособие. М.: Норма, 2003. С. 93.

16 Генеральный совет Федерального избирательного института Мексики является высшим руководящим органом, ответственным за реализацию конституционных норм и избирательных законов. 
приостановления избирательного права зависит от степени общественной опасности поведения субъекта права.

Запрет регистрации в качестве кандидата на выборах, существующий в избирательном праве Мексики, обладает рядом особенностей. Во-первых, данное лишение носит отложенный характер, поскольку возникает на более поздней стадии избирательного процесса (в отличие от классического лишения пассивного избирательного права кандидат на выборную должность сохраняет правовую возможность выдвижения на выборную должность). Во-вторых, анализируемое лишение пассивного избирательного права носит публично-частный характер: санкция применяется как в отношении политической партии, допустившей в соответствии со ст. 269 Избирательного кодекса Мексики нарушения на выборах, так и в отношении конкретного гражданина, желающего быть избранным. В-третьих, лишение субъективного избирательного права носит устранимый характер (лицо может вступить в другую политическую партию и баллотироваться от нее в качестве кандидата).

Еще одной разновидностью отложенного лишения пассивного избирательного права выступает объявление неизбираемости кандидата, предусмотренное французским законодательством. Неизбираемость проявляется в виде судебного решения о признании мандата недействительным и носит личный карательный характер: суды во Франции могут объявить о неизбираемости в течение 1 года кандидата, нарушившего порядок финансирования избирательной кампании. Неизбираемость является локальной мерой и применяется лишь к тому виду выборов, на которых кандидат допустил нарушения законодательства ${ }^{17}$.

Проведенный сравнительный анализ позволяет сделать вывод о наличии в зарубежных странах развитой системы лишений субъективного избирательного права, дифференцированных подходах к лишению избирательного права, а также о существовании особых видов лишения избирательного права в отдельных государствах. Современная штрафная политика большинства зарубежных стран сочетает ориентацию на предупреждение девиантного и противоправного поведения граждан; экономию репрессивных мер, применяемых к правонарушителям, подвергнутым лишению избирательного права; рациональное дополнение различных видов наказаний, учитывающее степень общественной опасности допущенных нарушений закона.

Красинский Владислав Вячеславович кандидат юридических наук, эксперт

${ }^{17}$ См. Зарубежное избирательное право: Учебное пособие. М.: Норма, 2003. С. 103. 
Российского общественного института избирательного права (РОИИП)

Красинский B.B. Лишение избирательного права в зарубежных странах // Журнал зарубежного законодательства и сравнительного правоведения. М.: Институт законодательства и сравнительного правоведения при Правительстве РФ, 2008. № 15 (вып. 4). С. 49-53 